\title{
Acute Toxicity Test of Pigeon Pea Leaves Extract (Cajanus cajan) in Rats
}

\author{
Tutik Wresdiyati ${ }^{1 *}$, Stephany Stephany ${ }^{1}$, Ekowati Handharyani ${ }^{2}$, Siti Sa'diah $^{1}$, and Made Astawan ${ }^{3}$ \\ ${ }^{1}$ Department of Anatomy, Physiology, and Pharmacology, Faculty of Veterinary Medicine, IPB University (Bogor Agricultural \\ University), IPB Darmaga Campus-Bogor 16880, Indonesia. \\ 2 Department of Clinic, Reproduction, and Pathology, Faculty of Veterinary Medicine, IPB University (Bogor Agricultural \\ University), IPB Darmaga Campus-Bogor 16880, Indonesia. \\ ${ }^{3}$ Department of Food Science and Technology, Faculty of Agricultural Technology, IPB University (Bogor Agricultural University), \\ IPB Darmaga Campus-Bogor 16880, Indonesia.
}

\begin{abstract}
Acute toxicity test was conducted to evaluate the safety level of pigeon pea (Cajanus cajan) leaves extract, using the Organisation for Economic Co-operation and Development (OECD 423) guideline method. The pigeon pea leaves were extracted using $96 \%$ ethanol as a solvent. A total of 9 male rats were used divided into 3 groups: 1 control group and 2 treatment groups. The rat in control group (group 1) received a single dose of distilled water while the rat in groups 2 and 3 received a single dose of pigeon pea leaves extract at doses of $300 \mathrm{mg} / \mathrm{kg} \mathrm{BW}$ and $2000 \mathrm{mg} / \mathrm{kg} \mathrm{BW}$, respectively. The aquadest and extract suspension were administered orally using rat stomach tubedos. Mortality and clinical signs were examined in the first 4 hours (critical time), 24 hours, and 14 days after the treatments. The result revealed that the $\mathrm{LD}_{50}$ values of the extract was estimated at more than $5000 \mathrm{mg} / \mathrm{kg} \mathrm{BW}$ and classified as practically nontoxic.
\end{abstract}

Keywords: acute toxicity, Cajanus cajan, $\mathrm{LD}_{50}$, rat.

\section{Introduction}

Indian-Cajanus cajan leaves extract was reported having a hypoglycemic effect [1]. Indonesian- Cajanus cajan is well known as 'kacang gude' or 'undis'. Quan and Liang [2] reported that the bioactive compound of a certain plant could be different depending on the ecology condition where it planted. Wresdiyati et al., [3] also reported that Indonesian Cajanus cajan leaves, especially from Lombok, West Nusa Tenggara, showed hypoglycemic activity in rats. So, for safety in using Cajanus cajan leaves as a candidate for antidiabetic, it's needed to test the toxicity of the leaves.

The acute toxicity test of a bioactive compound is generally carried out by determining the Lethal Dose value of $50 \%\left(\mathrm{LD}_{50}\right) . \mathrm{LD}_{50}$ is a dose of a substance that can kill $50 \%$ of the experimental animal population [4].

Since the conventional acute toxicity test using many experimental animals and not following the concept of animal welfare, it has begun to be replaced with new methods that use experimental animals in smaller amounts or even without using experimental animals at all $[5,6]$. One type of the new acute toxicity test is the OECD guideline no 423, which highlights the animal welfare side where the clinical symptoms of poisoning are endpoints of testing other than the death of experimental animals. In addition, this test also provides more information related to the target organ and the mechanism of poisoning [7].
This study aims to analyze the safety level of Indonesian Cajanus cajan leaves extract in Sprague Dawley rats through an acute toxicity test - $\mathrm{LD}_{50}$ that refers to OECD423 and changes in liver and kidney tissues of experimental rats.

\section{Materials and Methods}

\subsection{Materials}

This study used C. cajan leaves that were obtained from Lombok, West Nusa Tenggara, Indonesia. After picking, the $C$. cajan leaves were air-dried and then oven-dried at $50^{\circ} \mathrm{C}$, and the dried C. cajan leaves were ground and sifted using a $40 \mathrm{~mm}$ mesh [3]. A total of nine male Sprague-Dawley rats were used for the acute toxicity test in the present study.

\subsection{Methods}

\subsubsection{Cajanus cajan leaves extraction}

The extraction of $C$. cajan leaves was conducted by the maceration method using ethanol $96 \%$ as the solvents at a ratio of 1:5 for 24 hours then filtered. The maceration was repeated three times. The resulting filtrate was then dried using a vacuum evaporator to obtain dried extract [3]. 


\subsubsection{In vivo acute toxicity test in rats}

Rat care and experimental procedures in this study were in accordance with the Ethical Approval Letter from Animal Care and Use Committee, Bogor Agricultural University, number 132-2018 IPB, 30 November 2018.

A total of 9 male Sprague-Dawley rats were used for this study. They were divided into 3 groups, consisting of 1 control group and 2 treatment groups. The control group (C) was given distilled water as much as 2 $\mathrm{ml}$, while the treatment groups were given a solution of Cajanus cajan leaves extract with a dose referring to OECD423. The doses that were chosen in this study are $300 \mathrm{mg} / \mathrm{kg}$ body weight (T2) and $2000 \mathrm{mg} / \mathrm{kg}$ body weight (T3) (Figure 1). Intensive observations were conducted in the first 4 hours after administration of the extract solution, then continued with routine observations every 24 hours once for 14 days [8]. The main parameters observed to determine the Lethal Dose value of $50 \%$ $\left(\mathrm{LD}_{50}\right)$ were clinical symptoms of moribund, severe pain, and rat mortality. Rats that exhibit clinical symptoms of moribund and severe pain must be put to sleep in a welfare manner and counted as rat mortality during the trial period.

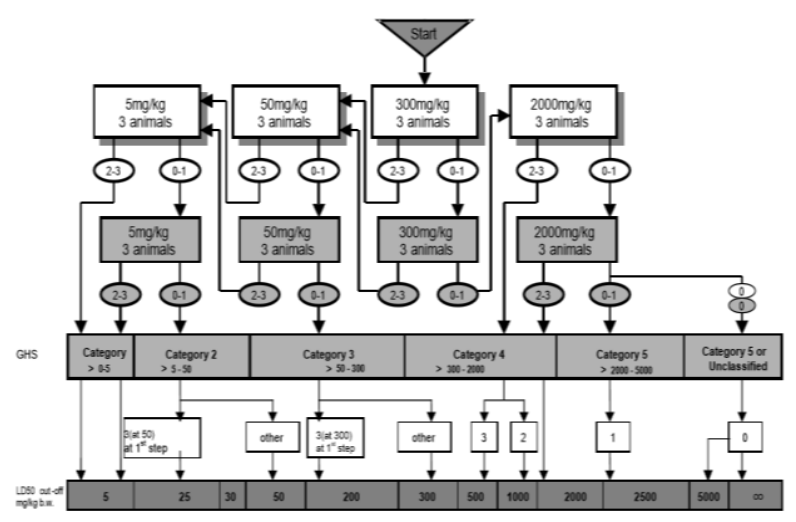

Figure 1. Procedure for acute toxicity and $\mathrm{LD}_{50}$ values test with a selected initial dose of $300 \mathrm{mg} / \mathrm{kg}$ body weight (OECD423 2001)

Determination of $\mathrm{LD}_{50}$ values based on the OECD423 method (Figure 1). The initial dose of the extract that was chosen is $300 \mathrm{mg} / \mathrm{kg}$ BW. If at the dose there are 2-3 death, then the test is followed by extract with reduced dose to $50 \mathrm{mg} / \mathrm{kg}$ body weight. If at the dose of $50 \mathrm{mg} / \mathrm{kg} \mathrm{BW}$ there is $0-1$ death, then the test is followed by extract at a higher dose, $2000 \mathrm{mg} / \mathrm{kg}$ body weight. If at this dose 3 dead rats are found, the $\mathrm{LD}_{50}$ value is $500 \mathrm{mg} / \mathrm{kg}$ body weight. If there are 2 dead rats, the $\mathrm{LD}_{50}$ value is $1000 \mathrm{mg} / \mathrm{kg}$ body weight, while if the number of death found is 1 rat, the $\mathrm{LD}_{50}$ value is 2500 $\mathrm{mg} / \mathrm{kg}$ body weight. If the dead rat at this higher dose is not found at all, then there is an option to immediately determine the $\mathrm{LD}_{50}$ value or carry out further testing at the maximum dose, which is $5000 \mathrm{mg} / \mathrm{kg} \mathrm{BW}$.

Testing at the maximum dose should only be done with several considerations including strong evidence that the $\mathrm{LD}_{50}$ value is between doses of $5000 \mathrm{mg} / \mathrm{kg}$ BB to infinity $(\infty)$, there is information on the symptoms of toxicity in humans, and death is found in testing doses of $2000 \mathrm{mg} / \mathrm{kg}$ body weight. If these requirements are not found, then testing with a maximum dose is not permitted to be carried out in order to protect the welfare of experimental animals. Without testing the maximum dose, $\mathrm{LD}_{50}$ values can be taken in the range of doses of $5000 \mathrm{mg} / \mathrm{kg}$ body weight to $\infty$ or $>5000 \mathrm{mg} / \mathrm{kg}$ body weight.

\subsubsection{SGOT, SGPT, Ureum, and Creatinin analysis}

Serum GPT, GOT, ureum, and creatinine were measured using an Automatic chemical analyzer (Vital Scientific N.V., The Netherlands). Serum GPT and GOT were measured using IFCC Mod without pyridoxal method, while serum ureum and creatinine were measured using urease and Jaffe without deproteination

\subsubsection{Histomorphological analysis of Liver and Kidney tissues}

The liver and kidney tissues were fixed using paraformaldehyde, then the tissues were processed using the paraffin embedding standard method. The tissue slices were stained using hematoxylin and eosin. The histomorphological study was observed under a light microscope.

\section{Results and Discussion}

\subsection{Lethal Dose 50\% $\left(\mathrm{LD}_{50}\right)$}

Acute toxicity testing aims to determine the level of toxicity of a compound by one of the ways to identify the $\mathrm{LD}_{50}$ value and the degree of toxicity from the $\mathrm{LD}_{50}$ value. $\mathrm{LD}_{50}$ values were obtained from the number of the rat with clinical symptoms of moribund, extreme pain, and death after treatment. Rat mortality due to administration of Cajanus cajan leaves extract was not found either in the observation 24 hours or 14 days after administration of the extract.

Death is not found at a dose of $2000 \mathrm{mg} / \mathrm{kg}$ body weight. The results of the acute toxicity test of $C$. cajan leaves extract ever conducted by Kevin et al (2018) using aquades and hydroethanolic solvents in Wistar strain rats, obtained LD L $_{50}$ values of each solvent are $3715.35 \mathrm{mg} / \mathrm{kg}$ BW and $1174.90 \mathrm{mg} / \mathrm{kg} \mathrm{BW}$, respectively. In addition, no information related to the symptoms of toxicity in humans or deaths were found at a dose of $2000 \mathrm{mg} / \mathrm{kg}$ body weight, so testing at the maximum dose is not permitted and $L D_{50}$ values are categorized in the range of dose of $5000 \mathrm{mg} / \mathrm{kg}$ body weight to infinity $(\infty)$ is based on the Globally Harmonized System [8] and is practically nontoxic according to Hodge and Sterner [9].

\subsection{The profile of SGOT, SGPT, Ureum, and Creatinin}

The profile of serum glutamate oxalate transaminase (SGOT), serum glutamate piruvate transaminase (SGPT), ureum, and creatinin of the control group $(\mathrm{C})$, and treated 
groups; $300 \mathrm{mg} / \mathrm{kg}$ body weight (T1) and $2000 \mathrm{mg} / \mathrm{kg}$ body weight (T2) was showed in Table 1 .

Table 1. The profile of SGOT, SGPT, ureum, and creatinin of treated rats

\begin{tabular}{crrcc}
\hline Group & SGOT (U/l) & SGPT (U/l) & $\begin{array}{c}\text { Ureum } \\
(\mathrm{mg} / \mathrm{dl})\end{array}$ & $\begin{array}{c}\text { Creatinin } \\
(\mathrm{mg} / \mathrm{dl})\end{array}$ \\
\hline $\mathrm{C}$ & $116.67 \pm 30.89$ & $29.33 \pm 3.21$ & $47.67 \pm 1.15$ & $0.58 \pm 0.02$ \\
$\mathrm{~T} 1$ & $100.67 \pm 34.96$ & $31.00 \pm 2.00$ & $52.33 \pm 7.23$ & $0.47 \pm 0.24$ \\
$\mathrm{~T} 2$ & $102.00 \pm 25.24$ & $30.67 \pm 6.11$ & $50.33 \pm 9.07$ & $0.59 \pm 0.04$ \\
\hline
\end{tabular}

All parameters for liver and kidney tissue injury indicators showed no significant difference among treated groups. All parameters of the control and treated group are in a normal range of rats $[10,11]$. It means there is no tissue damage in both liver and kidney. In another way, the $C$. cajan extract is not a toxic agent.

\subsection{Histomorphological observation of liver and kidney tissues}

The liver tissues of treated rats were shown in Figures 2. Administration of C. cajan leaves extract showed changes in the Kiernan triangle area. Changes were found in the form of inflammatory cell infiltration and denaturation of hepatocyte cell nucleus proteins, while necrose (cell death) was not found.

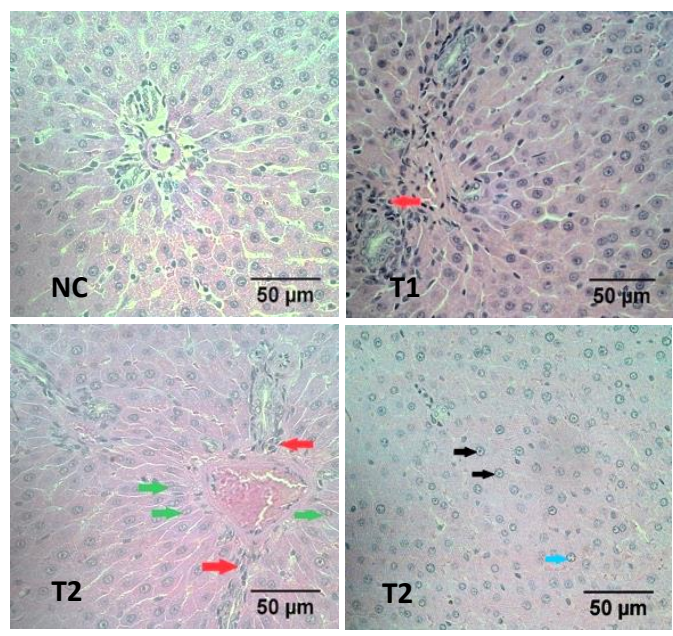

Figure 2. Micrograph of rats liver tissues in the Kiernan area showed a few numbers in inflammatory cell proliferation (red arrow), bile duct proliferation (blue arrow) and protein denaturation in the nuclei (black arrow). Staining with hematoxylin \& eosin

Acute inflammatory cell infiltration is generally caused by an acute hepatitis virus infection, autoimmune diseases [12], or side effects from drugs [13] including herbal medicines [14]. This inflammation is common in oral drugs that are metabolized by the liver [15].

The most common cause of denaturation is extreme temperatures, but some chemicals can also cause denaturation of this protein. Protein denaturation can be reversible or irreversible depending on how much damage is caused and how long the exposure of the material causing the denaturation. In denaturation that is reversible, the cell will be able to return to normal function if the exposure to the material causing the denaturation is stopped. In irreversible denaturation, the liver can regenerate as long as the number of healthy hepatocyte cells is not less than $25 \%$ [16].

According to Kleiner [17], acute damage is generally characterized by lobular changes, while changes in the Kiernan triangle area are generally characteristic of chronic damage. However, in the case of drugs that induce damage to the liver, symptoms of acute hepatitis make it possible to bring up histopathological features with patterns of inflammation such as chronic damage. Overall damage that occurs to the liver both at a dose of 300 $\mathrm{mg} / \mathrm{kg}$ body weight and $2000 \mathrm{mg} / \mathrm{kg}$ body weight can be categorized as mild or mild damage due to changes that occur only in a small area in the Kiernan triangle.

The kidney tissues of treated rats were shown in Figure 3. Administration of $C$. cajan leaves extract showed changes in the renal corpuscles and distal renal tubules. Changes were found in the form of Bowman's space dilatation and protein deposition in the distal renal tubules, while cell necrose was also not found.

Bowman's space expansion is generally caused by glomerular problems both atrophy [18] and an increased infiltration rate [19]. According to Radhakrishnan and Perazella [20], glomerular damage is quite common as a side effect of drugs in which endothelial cells are the cells most often damaged due to the influence of these medications. The damage to endothelial cells and the regeneration process is thought to cause atrophic glomerular appearance. On the other hand, the presence of certain drugs in the body can increase the process of creatinine removal which causes primary urine storage to increase in the Bowman room so that the Bowman room has expanded [21].
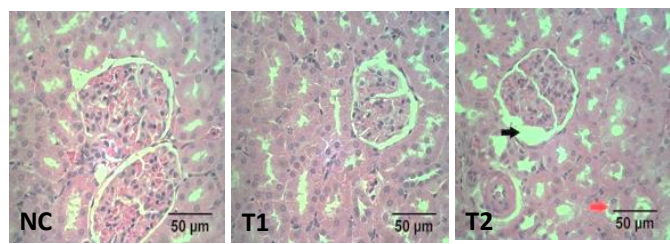

Figure 3. Photomicrograph of rats kidney tissues showed a few numbers in dilatation of Bowman space (black arrow), protein precipitation in distal tubule (red arrow). S Staining with hematoxylin \& eosin staining with hematoxylin \& eosin

Other changes include protein deposition in the distal renal tubular lumen which can be caused by a disruption in glomerular filtration, failure of the proximal tubules to reabsorb protein from the primary urine, or a combination of both [22, 23]. Glomerular endothelial cell damage as mentioned previously is thought to be the cause of leakage of protein into the urine on observations of the T3 group micrograph, while the proximal tubules do not appear to be altered.

According to the Acute Dialysis Quality Initiative (ADQI), acute damage to the kidneys is classified into risk, injury, kidney failure, loss of kidney function, and end-stage kidney disease or commonly referred to as 
classification RIFLE. While the Acute Kidney Injury Network (AKIN) adapted from the RIFLE classification with several updates, obtaining the results of the acute division of kidney damage into 3 categories, namely stage 1 for mild damage conditions, stage 2, and stage 3 for severe damage conditions. Both of these methods use serum creatinine levels, glomerular filtration rate, and urine output as a standard for determining the degree of damage so that determining the degree of damage only by looking at micrographs without accompanying laboratory results from urine is difficult to use to determine the degree of damage to the kidneys of these experimental rats [24]. In the present study, the value of SGOT, SGPT, ureum, and creatinin of ethanolic $C$. cajan extract-treated rats at a dose of $300 \mathrm{mg} / \mathrm{kg} \mathrm{BW}$ and $2000 \mathrm{mg} / \mathrm{kg} \mathrm{BW}$ supported that there is no any alteration in the liver and kidney function.

\section{Conclusion}

The present study concluded that the $\mathrm{LD}_{50}$ value of $C$. cajan leaves extract is greater than $5000 \mathrm{mg} / \mathrm{kg} \mathrm{BW}$ and is classified as practically non-toxic. Histopathological evidence in liver and kidney tissues are categorized as mild. The extract did not affect the function of rats liver and kidney.

\section{Acknowledgments}

Authors would like to thank the Directorate General of Higher Education, at the Ministry of Research, Technology and Higher Education, Indonesia, for supporting this work through "Penelitian Dasar Unggulan Perguruan Tinggi” 2019 awarded to Tutik Wresdiyati.

\section{References}

1. Nahar L, Nasrin F, Zahan R, et al.: Comparative study of antidiabetic activity of Cajanus cajan and Tamarindus indica in alloxan-induced diabetic mice with a reference to in vitro antioxidant activity. Pharm Res. $2014 ; 6(2): 180-187$.

2. Quan M, Liang J: The influences of four types of soil on the growth, physiological, and biochemical characteristics of Lycoris aurea (L'Her.) herb. Sci Rep. 2017;7:43284.

3. Wresdiyati T, S Sa'diah, M Astawan :The Antioxidant, Alpha-Glucosidase Inhibition and Hypoglycemic Activities of Cajanus cajan Leaves and Zingiber officinale var. Amarum. JAPS,2019 (under review).

4. Chinedu E, Arome D, Ameh FS: A new method for determining acute toxicity in animal models. Toxic Inter. 2013;20(3):224-226.

5. Jen-Yin G, Richard JW, Libby D, et al. : Development and use of in vitro alternatives to animal testing by the pharmaceutical industry 1980-2013. Toxicol Res. 2015;4:1297-1307.

6. Doke SK, Dhawale SC : Alternatives to animal testing: a review. Saudi Pharm J. 2015 ;23:223.

7. Saganuwa SA: Toxicity study of drugs and chemicals in animals: an overview. BJVM. 2016; 1311-1477.
8. [OECD423] The Organization for Economic Co-Operation and Development. OECD Guideline for Testing of Chemicals: Acute Oral Toxicity - Acute Toxic Class Method. USA: The Organization for Economic CoOperation and Development. 2001.

9. Hodge A, Sterner B: 2005. Toxicity Classes. https://www.ccohs.ca/oshanswers/chemicals/ld50.html

10. Fitriani U, Dewi TF, Wijayanti E: Analysis of liver function and kidney function in rats after giving Piper retrofractum, Plantago major and Apium graveolens. PROS SEM NAS MASY BIODIV INDON. ISSN: 24078050. 2019;5(2):263-266.

11. Roosdiana A, Hendrawan VF, Wulandari M : The rice bran as therapy agent to decrease the SGOT/SGPT activities and improve the Histopathology of liver in white rat (Rattus norvegicus) induced by high cholesterol diet. IOP Conference Series: Materials Science and Engineering. $2019 ; 546$. 062026. DOI : $10.1088 / 1757-899 X / 546 / 6 / 062026$.

12. Manns MP, Lohse AW, Vergani D: Autoimmune hepatitis. J Hepatol. 2015 ;62(1):S100-S111.

13. Fontana R, Hayashi $\mathrm{P}$ : Clinical features, diagnosis, and natural history of drug-induced liver injury. Seminars in Liver Disease. 2014 ;34(2):134-144.

14. David S, Hamilton JP. Drug-induced liver injury. US Gastroenterol Hepatol Rev. $2011 ; 6: 73-80$.

15. Lammert C, Bjornsson E, Niklasson A, et al. : Oral medications with significant hepatic metabolism at higher risk for hepatic aderse events. Hepatol. $2010 ; 51: 615-620$.

16. Fausto N, Campbell JS, Riehle KJ : Liver regeneration. Hepatology, 2006 ; 43:S45-S53.

17. Kleiner DE: The histopathological evaluation of druginduced liver injury. Histopathology. 2017; 70(1): 81-93. DOI: $10.1111 /$ his.13082

18. Kotyk T, Dey N, Ashour AS, et al. : Measurement of the glomerulus diameter and bowman's space thickness of renal albino rats. Comput Methods Prog Biomed. $2016 ; 126: 143-153$.

19. Cachat F, Combescure C, Cauderay M, et al: A systematic review of glomerular hyperfiltration assessment and definition in the medical literature. Clin J Am Soc Nephrol. 2015 ;10(3):382-389.

20. Radhakrishnan J, Mark A, Perazella MA: Drug-Induced Glomerular Disease: Attention Require!. Clin J Am Soc Nephrol. 2015; 10:1287-1290. doi: 10.2215/CJN.01010115.

21. Bellomo R, Wan L, May $\mathrm{C}$ : Vasoactive drugs and acute kidney injury. Crit Care Med. 2008 ;36:S179-S186.

22. Tojo A, Kinugasa S: Mechanisms of glomerular albumin filtration and tubular reabsorption. Int J Nephrol. 2012; 481520.

23. Tojo A, Onozato $\mathrm{M}, \mathrm{Ha} \mathrm{H}$, et al.: Reduced albumin reabsorption in the proximal tubule of early-stage diabetic rats. Histochem Cell Biol. 2001; 116(3):269-276.

24. Lopes JA, Jorge $S$ : The RIFLE and AKIN classifications for acute kidney injury: a critical and comprehensive review. Clin Kidney J. 2013; 6(1): 8-14. 